\title{
Respiration under Control of Uncoupling Proteins: Clinical Perspective
}

\author{
T. Nübel D. Ricquier \\ Centre National de la Recherche Scientifique, Unit 9078, Faculty of Medicine René Descartes Paris 5, \\ Paris, France
}

\section{Key Words}

Uncoupling proteins - Energy metabolism •

Thermogenesis · Body weight control $\cdot$ Mitochondria

\begin{abstract}
The term 'uncoupling protein' was originally used for the mitochondrial membrane protein UCP1, which is uniquely present in mitochondria of brown adipocytes, thermogenic cells that regulate body temperature in small rodents, hibernators and mammalian newborns. In these cells, UCP1 acts as a proton carrier activated by free fatty acids and creates a shunt between complexes of the respiratory chain and ATP-synthase resulting in a futile proton cycling and dissipation of oxidation energy as heat. Recent identification of new homologues to UCP1 expressed in brown and white adipose tissue, muscle, brain and other tissues together with the hypothesis that these novel uncoupling proteins (UCPs) may regulate thermogenesis and/or fatty acid metabolism and furthermore may protect against free radical oxygen species production have generated considerable optimism for rapid advances in the identification of new targets for pharmacological management of complex pathological syndromes such as obesity, type 2 diabetes or chronic inflammatory diseases. However, since the physiological and biochemical roles of the novel UCPs are not yet
\end{abstract}

clear, the main challenge today consists first of all in providing mechanistic explanation for their functions in cellular physiology. This lively awaited information may be the basis for potential pharmacological targeting of the UCPs in future.

Copyright (ㅇ 2006 S. Karger AG, Basel

\section{Introduction}

In the last three decades mitochondria were recognized not only as simple energy generators harbouring oxidative metabolic reactions, but also as organelles also regulating various physiological phenomena such as calcium homeostasis or free radical generation as well as playing a key role in the signaling cascade of apoptosis. Thus, new roles for regulated respiration uncoupling mediated by mitochondrial carrier proteins as for example the adenine nucleotide translocase [1-3] but especially by members of the UCP family were found. Uncoupling proteins (UCPs) and respiration uncoupling seem to be implicated in numerous physiological and pathological processes of great importance, which becomes clear from this simple list of proposed UCP-functions: adaptive thermogenesis $[4,5]$, regulation of fatty acid oxidation $[6,7]$, participation in inflammation [8], prevention of reactive oxygen species (ROS) formation [9, 10], regulatory func-

\section{KARGER \\ Fax +4161306 1234 E-Mail karger@karger.ch} www.karger.com
(C) 2006 S. Karger AG, Basel 0301-0163/06/0656-0300\$23.50/0

Accessible online at: www.karger.com/hre
D. Ricquier

Faculty of Medicine René Descartes Paris 5, Site Necker

CNRS - UPR 9078 (7e étage), 156, rue de Vaugirard

FR-75730 Paris Cedex 15 (France)

Tel. +33140615670, Fax +33140615673, E-Mail ricquier@necker.fr 
Fig. 1. Coupling of energy at the inner membrane of mitochondria. The respiratory chain pumps protons $\left(\mathrm{H}^{+}\right)$across the mitochondrial inner membrane (MIM) and generates a proton gradient. Energy used for this process is released from a redox-reaction whereby reduction equivalents $(\mathrm{R}-\mathrm{H})$ are oxidized by molecular oxygen $\left(\mathrm{O}_{2}\right)$ which itself in turn gets reduced to water. Incomplete oxygen reduction leads to production of ROS inducing cellular oxidative stress and damage. ATP synthase transforms ADP and organic phosphate $\left(\mathrm{P}_{\mathrm{i}}\right)$ into ATP using the energy conserved in the $\mathrm{H}^{+}$ gradient. Besides these tightly coupled processes protons leak back across the membrane using UCP or non-protein membrane pores (Leak). This 'uncoupling' dissipates the $\mathrm{H}^{+}$gradient as heat.

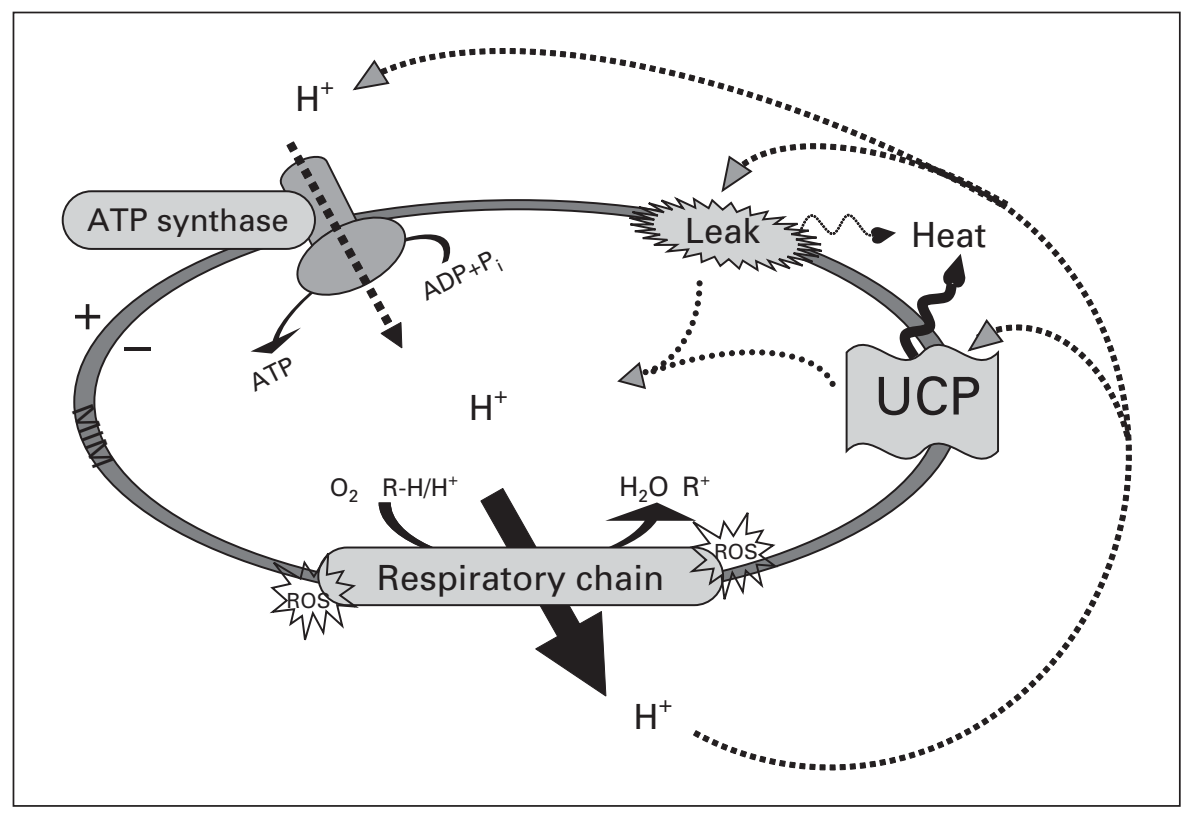

tions in type 2 diabetes [11], body weight regulation [12], prevention of atherosclerosis [13] and ageing [14]. A potentially protective role of at least one of the UCPs, i.e. $\mathrm{UCP} 2$, in cancer development is also discussed $[15,16]$.

Realizing that all these physiological and pathological features considered to be connected to respiration uncoupling are at the top of the list of the most challenging diseases of our time, the question arises as to the therapeutic potential of UCPs. The ultimate prerequisite for the development of pharmaceutical strategies using UCPs as target structures is a large knowledge of the mechanistic action and physiological function of these mitochondrial proteins.

\section{Respiration Uncoupling and Energy Expenditure}

Coenzymes NADH and $\mathrm{FADH}_{2}$ generated in the citric acid cycle during fuel oxidation are reoxidized passing electrons to the respiratory electron transport chain. The electron transport in the respiratory chain pumps $\mathrm{H}^{+}$ across the inner mitochondrial membrane from the matrix to the intermembrane space. This creates an electrochemical $\mathrm{H}^{+}$gradient, named proton motive force, which provides energy for adenosine triphosphate (ATP) synthesis by the ATP synthase. At least three protons are required to synthesize one ATP in the process of the socalled oxidative phosphorylation $[17,18]$. The efficiency in use of the formed $\mathrm{H}^{+}$gradient by the ATP synthase is called coupling. Hence 100\% coupling would exist, if the machinery of the oxidative phosphorylation would work at the expense of the whole proton gradient formed [17]. However, the $\mathrm{H}^{+}$gradient is not only consumed by the ATP synthase, but also by carrier structures in the inner mitochondrial membrane like adenosine diphosphate (ADP)/ATP carrier, calcium carrier or glutamate/aspartate carrier, due to charge imbalance of their substrates [19]. A further part of the proton motive force is consumed by the phosphate carrier and other carriers employing substrate/ $\mathrm{H}^{+}$symport [19]. These mechanisms allow $\mathrm{H}^{+}$backflow to the matrix bypassing ATP synthase and thereby provoke protein-mediated respiration uncoupling. Additionally, under normal conditions, a portion of the created $\mathrm{H}^{+}$gradient is consumed by proton backflow to the matrix via non-protein membrane pores or protein/lipid interfaces and this is called $H^{+}$leak [20,21]. Thus, uncoupling is an inherent part of mitochondrial physiology.

\section{Physiological Regulators of Protein-Mediated Respiration Uncoupling: The Family of the UCPs}

UCPs are mitochondrial transporters present in the inner membrane of mitochondria (fig. 1). They are found in all mammals and in plants and belong to the family of 
Table 1. Demonstrated and proposed roles for mammal uncoupling proteins

\begin{tabular}{|c|c|c|c|c|c|c|}
\hline & UCP1 & UCP2 & UCP3 & UCP4 & BMCP1 & KMCP1 \\
\hline $\begin{array}{l}\text { Main tissue } \\
\text { distribution }\end{array}$ & BAT & Ubiquitous & Skeletal muscle & $\begin{array}{l}\text { Central nervous } \\
\text { system }\end{array}$ & Brain & Kidney \\
\hline $\begin{array}{l}\text { Physiological } \\
\text { role }\end{array}$ & $\begin{array}{l}\text { Thermogenesis } \\
\text { Limitation of ROS? }\end{array}$ & $\begin{array}{l}\text { Insulin secretion } \\
\text { Thermogenesis? } \\
\text { Limitation of ROS } \\
\text { and/or ATP? }\end{array}$ & $\begin{array}{l}\text { Thermogenesis? } \\
\text { Limitation of ROS } \\
\text { and/or ATP? } \\
\text { Fatty acid metabolism? }\end{array}$ & $\begin{array}{l}\text { Thermogenesis? } \\
\text { Limitation of ROS } \\
\text { and/or ATP? }\end{array}$ & $\begin{array}{l}\text { Thermogenesis? } \\
\text { Limitation of } \\
\text { ROS and/or ATP? }\end{array}$ & $\begin{array}{l}\text { Thermogenesis? } \\
\text { Limitation of } \\
\text { ROS and/or ATP? } \\
\text { Transport of } \\
\text { glutathione? }\end{array}$ \\
\hline $\begin{array}{l}\text { Pathological } \\
\text { implication }\end{array}$ & $\begin{array}{l}\text { Cold intolerance } \\
\text { Obesity }\end{array}$ & $\begin{array}{l}\text { Regulation of } \\
\text { inflammatory events? } \\
\text { Protection against } \\
\text { atherosclerosis, ageing } \\
\text { and diabetes? } \\
\text { Progression of cancer? } \\
\text { Neuroprotection? }\end{array}$ & $\begin{array}{l}\text { Obesity? } \\
\text { Proapoptotic effects? } \\
\text { Progression of cancer? }\end{array}$ & $\begin{array}{l}\text { Neuromodulation? } \\
\text { Neuroprotection } \\
\text { against apoptosis? }\end{array}$ & $\begin{array}{l}\text { Nervous system } \\
\text { signaling via ROS? }\end{array}$ & \\
\hline
\end{tabular}

ATP = Adenosine triphosphate BAT $=$ brown adipose tissue ROS = reactive oxygen species; $\mathrm{UCP}=$ uncoupling protein; $?=$ proposed roles.

mitochondrial anion carriers including for example the adenine nucleotide translocase [22]. It is widely accepted that the function of the original UCP, namely UCP1, is uncoupling of oxidative respiration from ATP synthesis, and that its physiological purpose is adaptive thermogenesis. UCP1, which is uniquely present in mitochondria of brown adipocytes, acts as a proton carrier activated by free fatty acids and enhances respiration and cellular heat production after its activation [23]. However, in humans and other large mammals, brown adipose tissue (BAT) disappears after infancy and there is minimal or no detectable UCP1 expression in adults [22].

Physiological functions and mechanistic action of the novel UCPs, identified in mammals within the past 9 years, are as yet poorly understood (table 1). These proteins include UCP2, UCP3, UCP4, BMCP1 (UCP5) and KMCP1 [22, 24-28]. UCP2 is ubiquitous and highly expressed in the lymphoid system, macrophages, and pancreatic islets [26]. UCP3 is mainly expressed in skeletal muscles [27]. Amino acid sequence similarity of UCP2 and UCP 3 to UCP1 is 55 and 57\%, respectively. It is of significance to note, however, that UCP4, BMCP1 and KMCP1 have only $30 \%$ similarity to UCP1 in amino acid sequence $[4,24,25,28]$. UCP4 and BMCP1 are predominantly expressed in the central nervous system $[24,28]$, whereas KMCP1 is the UCP representative in kidney [25]. These latter mentioned three UCPs seem to be the ancestral prototype and phylogenetic analyses indicate that there are other mitochondrial anion carrier proteins more closely structurally aligned to UCP1 [4, 29].
In comparison to the established uncoupling and thermogenic activities of UCP1, UCP2 and UCP3 appear to be involved in the limitation of free radical levels in cells rather than in physiological uncoupling and thermogenesis $[4,30,14]$. Moreover, UCP2 is discussed to be a putative regulator of insulin secretion and UCP 3 could be involved in fatty acid metabolism [11,31]. So far however, the physiological and biochemical roles of these inner mitochondrial membrane proteins are uncertain. Furthermore, there is very little information available about physiological functions of UCP4, BMCP1 and KMCP1.

\section{Experimental Evidence for Physiological Roles and Implication of UCPs in Pathological Events}

\section{UCP-Mediated Adaptive Thermogenesis}

One of the biggest energy expenditures in the mammalian body is thermal energy (heat). The production of this heat is called thermogenesis and can be divided in different types. Besides the work-induced type from exercise that heats up muscles the so-called thermo-regulatory form of thermogenesis is involved in keeping the temperature of the human body regulated. There are two types of thermo-regulatory or also called adaptive thermogenesis: the non-shivering and the muscle-mediated shivering one. Non-shivering thermogenesis also fits into a third and a fourth classification, which comprise diet-induced thermogenesis and cold-induced thermogenesis. 
Table 2. Overview of the discussed UCP knock-out and knock-in models and their phenotypes

\begin{tabular}{|c|c|c|c|}
\hline Strategy & $\begin{array}{l}\text { Model } \\
\text { system }\end{array}$ & Phenotype & References \\
\hline $\begin{array}{l}\text { Targeted disruption } \\
\text { of the UCP1 gene }\end{array}$ & mouse & Cold sensitive & 33 \\
\hline $\begin{array}{l}\text { Targeted disruption } \\
\text { of the UCP } 2 \text { gene }\end{array}$ & mouse & 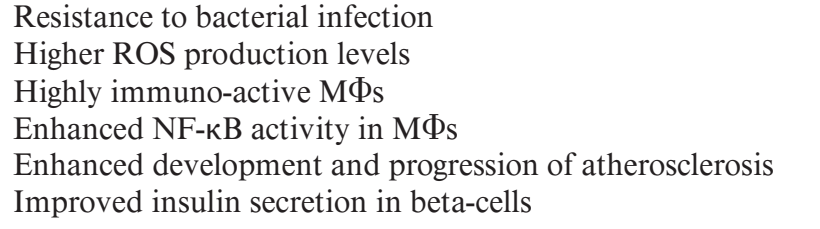 & $8,11,13,42,43,55$ \\
\hline $\begin{array}{l}\text { Transgenic or adenoviral } \\
\text { UCP1 overexpression }\end{array}$ & mouse & $\begin{array}{l}\text { Increased metabolic rates } \\
\text { Lower levels of blood glucose, insulin and cholesterol } \\
\text { Decreased ROS production } \\
\text { Prevention of diet-induced insulin resistance, hypertension, } \\
\text { hyperphagia, hypothalamic leptin resistance and obesity } \\
\text { Activation of eNOS in VSCM }\end{array}$ & $45,47,49,50$ \\
\hline $\begin{array}{l}\text { Tansgenic, adenoviral } \\
\text { or retroviral UCP2 } \\
\text { overexpression }\end{array}$ & $\begin{array}{l}\text { in vivo: } \\
\text { fly neurons } \\
\text { in vitro: } \\
\text { insulinoma } \\
\text { cells, HeLa } \\
\text { cells, VSMC }\end{array}$ & $\begin{array}{l}\text { Decreased respiratory control ratio } \\
\text { Diminished mitochondrial membrane potential } \\
\text { Higher proton conductance of mitochondrial membrane } \\
\text { Decreased ROS production levels and oxidative damage } \\
\text { Reduced mitochondrial NADH and intracellular ATP levels } \\
\text { Prevention of atherosclerotic processes } \\
\text { Extended life span of flies }\end{array}$ & $16,37,46,65$ \\
\hline $\begin{array}{l}\text { Transgenic or adenoviral } \\
\text { UCP3 overexpression }\end{array}$ & mouse & $\begin{array}{l}\text { Decreased respiratory control ratio } \\
\text { Diminished mitochondrial membrane potential } \\
\text { Higher proton conductance of mitochondrial membrane } \\
\text { Resistance to diet-induced obesity and hyperphagia } \\
\text { Increased glucose clearance rate }\end{array}$ & $12,36,37,61$ \\
\hline
\end{tabular}

eNOS = Endothelial nitric oxide synthase; $\mathrm{M} \Phi_{\mathrm{S}}=$ macrophages; NF-кB = nuclear factor-kappaB; ROS = reactive oxygen species; $\mathrm{UCP}=$ uncoupling protein; VSCM = vascular smooth muscle cells.

Especially BAT, through the activity of UCP1, is responsible for non-shivering thermogenesis in newborn humans and in small mammals [32] (table 2). UCP1-mediated heat production causes a decrease in efficiency of oxidative phosphorylation leading to increased fat oxidation and to diminution in feed efficiency (ratio of weight gain to food intake) [32]. Mice that do not express UCP1 (UCP1 knock-outs) are markedly cold sensitive [33]. Recent identification of new homologues to UCP1 expressed in BAT, muscle, white adipose tissue, brain and other tissues together with the hypothesis that these novel UCPs may regulate thermogenesis and/or fatty acid metabolism have generated considerable optimism for rapid advances in molecular understanding of adaptive thermogenesis and for the identification of new targets for pharmacological management of obesity [34]. Intensive research activity, however, led to significantly controversial results and a lively on-going debate about the physiological importance of the UCP1 homologues in thermogenesis and fuel/lipid oxidation. Whether e.g. UCP2 and UCP3 actually function as uncouplers is controversially discussed [4, 35]. Mitochondria from mice overexpressing human UCP3 in skeletal muscle have been shown to have a decreased respiratory control ratio and a diminished membrane potential, both suggestive for a decrease in coupling $[12,36]$. Proton conductance was 4-fold greater in mice overexpressing UCP3 than in wild-type controls [36]. These and other studies support the contention that UCP2 and UCP3 are uncouplers of oxidative phosphorylation $[26,27,37]$. In relation to neuronal functions an exciting and provocative aspect of controlled mitochondrial uncoupling by UCPs - especially UCP2, UCP4 and BMCP1 - is 
Fig. 2. Proposed physiological roles and possible implication of uncoupling proteins in pathological events. UCPs are described to play regulatory roles in cellular ageing, apoptosis and cancer development by limiting ROS generation, and in the case of inflammation and atherosclerosis they are even reported to exert supportive and protective functions. By promoting fatty acid oxidation and energy expenditure they influence either directly or indirectly regulation of body weight and of thermogenesis, furthermore they may increase fat catabolism in cancer cachexia. Limitation of ATP synthesis by uncoupling action of UCP is proposed to be a putative mechanism by which they could influence changes in cellular metabolism during tumour formation and ageing but also during loss of beta-cell function in diabetes. The ability of UCP to induce thermogenesis leads to their potential implication in regulation of body weight and cellular fat metabolism.

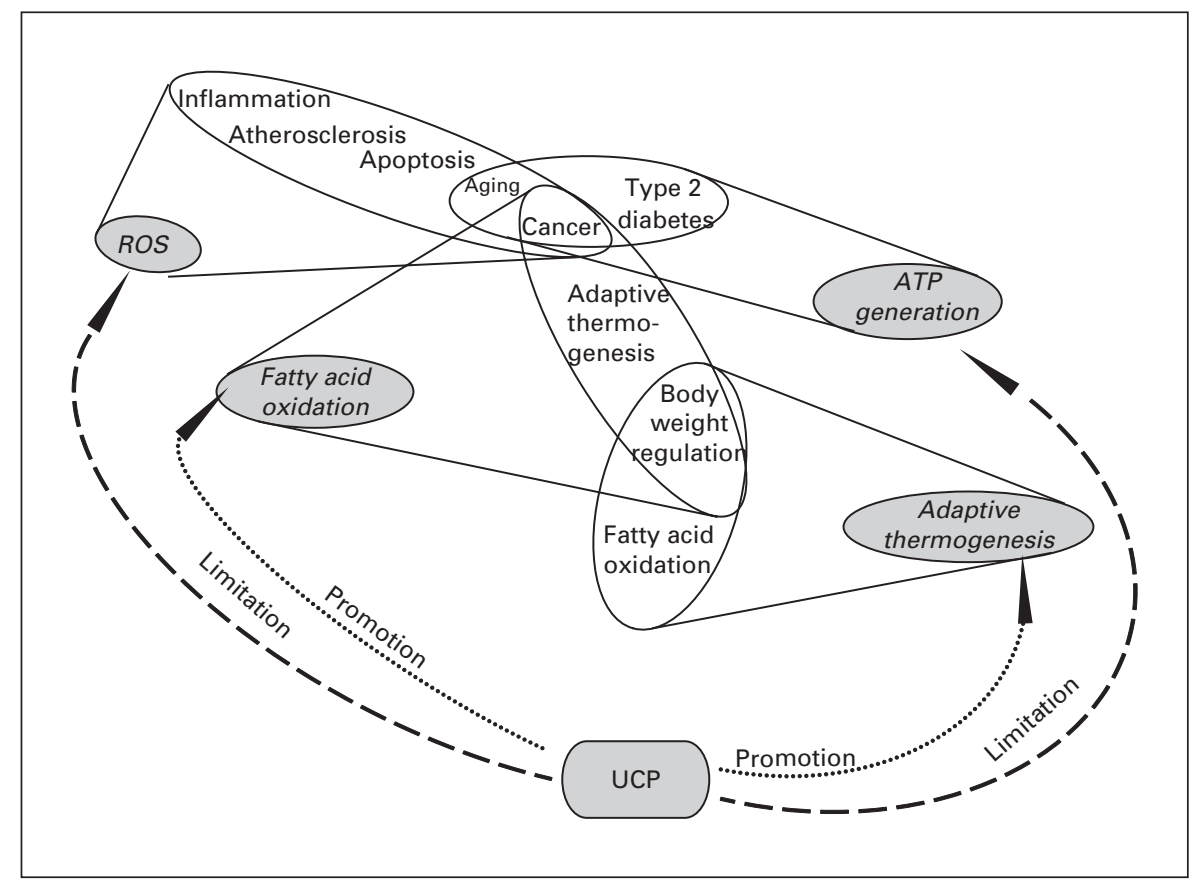

the potential to affect the temperature in the microenvironment of presynaptic terminals and hence to provide a basis for temperature as a neuromodulator [38, 39]. However, in summary satisfying answers to fundamental questions regarding the metabolic functions of the new UCPs are pending and more research is needed to elucidate their physiological functions in thermogenesis (fig. 2).

\section{Involvement of UCPs in Inflammation}

Inflammation is one of the most important cellular pathophysiological processes involving free radicals generated by mitochondria. According to the state of mitochondrial respiration, the respiratory chain generates superoxide anions, which are converted into hydrogen peroxide or hydroxyl-radicals; all summarized in the term ROS [40]. Altogether, till now published results strongly suggest that UCPs, particularly UCP2, are able to modulate mitochondrial ROS generation [41]. Expression of $\mathrm{UCP} 2$ is robust in spleen, lung and isolated macrophages, suggesting a role for UCP 2 in immunity or inflammatory responsiveness [8]. Investigation of the response to infection with Toxoplasma gondii in mice with targeted disruption of the UCP2 gene (Ucp $2^{-/-}$) showed a complete resistance to infection, in contrast with lethality observed in wild-type littermates. Macrophages from Ucp $2^{-/-}$mice generated more ROS than that of wild-type mice in response to infection and had a 5-fold greater toxoplasma- cidal activity in vitro compared with wild-type mice [8]. This supports a role for UCP2 in limitation of ROS and macrophage-mediated immunity. The molecular mechanisms of this elevated immune response of Ucp $2^{-/-}$mice were proposed to base on remarkably enhanced key steps in the activation cascade of nuclear factor-kappaB, including augmented I kappaB kinase activity and nuclear translocation of nuclear factor-kappaB subunits [42]. This in turn leads to higher expression of inducible nitricoxide synthase and inflammatory cytokines [42]. From these results it was concluded that mitochondrial derived reactive oxygen from $\mathrm{Ucp}^{-/-}$cells constitutively activates nuclear factor-kappaB, resulting in a 'primed' state to both potentiate and amplify the inflammatory response upon subsequent stimulation [42, own unpublished data]. Furthermore, the reported down-regulation of UCP2 in immune cells during their activation in early stages of the response to bacterial lipopolysaccharides followed by upregulation in UCP2 expression during later stages to protect all cells against oxidative stress [43] as well as a described decrease in UCP2 levels in ovarian cells during follicular growth but increased expression during the preovulatory period, during which aspects of an inflammatory process are known to exist [44], represent further strong experimental evidences for a direct link of presence and action particularly of UCP2 and the regulation of inflammatory events. 


\section{Preventive Functions of UCPs in Atherosclerosis}

In patients with diabetes mellitus increased oxidative stress especially in smooth muscle cells of vessels has been suggested to be implicated in the pathogenesis of accelerated atherosclerosis. A major factor in ROS-dependent pathogenesis of atherosclerosis under diabetic conditions and hypertension are high levels of blood glucose. Hyperglycaemia-induced mitochondrial superoxide overproduction inhibits among others eNOS activity [45], a main regulator of blood pressure acting in a vasodilatatory manner. Changes in eNOS activity were found in aortas from diabetic animals in vivo [45]. Inhibition of eNOS by ROS is reversed by blocking mitochondrial superoxide production by overexpression of UCP1 under hyperglycaemic conditions [45]. Since UCP2 is also described as an important regulator of intracellular ROS production [8], the stimulating hypothesis arises that UCP2 could function as an inhibitor of the atherosclerotic process. Park et al. [46] demonstrated that UCP2 by adenovirusmediated transfer of the UCP2 gene could modify atherosclerotic processes in smooth muscle cells of vessels in response to high glucose. The authors proposed agents increasing UCP2 expression in vascular cells as potential preventive tools in counteracting development and progression of atherosclerosis in patients with diabetes and hypertension [46]. Since the mechanisms linking hypertension and insulin resistance are poorly understood, another approach was performed by crossing transgenic mice expressing UCP1 in skeletal muscle with lethal yellow $(\mathrm{A}(\mathrm{y}) / \mathrm{a})$ mice, genetically obese animals known to have elevated blood pressure [47]. Blood pressure and serum leptin were lower in uncoupled offspring mice than in parental $(\mathrm{A}(\mathrm{y}) / \mathrm{a})$ mice, what indicates that respiratory uncoupling under certain circumstances is able to reverse insulin resistance and to lower blood pressure in genetic obesity. Thus, experimental in vivo evidences demonstrate that a controlled respiratory uncoupling could decrease the risk of atherosclerosis in type 2 diabetes by preventing insulin resistance-related hypertension [47]. Interestingly, when non-diabetic low-density lipoprotein receptor-deficient mice $\left(\mathrm{LDLR}^{-/}\right)$were transplanted with bone marrow from either UCP2-deficient mice $\left(\mathrm{Ucp} 2^{-/-}\right)$or wild-type mice $\left(\mathrm{Ucp} 2^{+/+}\right)$, a marked increase in atherosclerotic lesion size in the thoracic aorta as well as in the aortic sinus of $\mathrm{Ucp} 2^{-/-}$transplanted mice compared with control Ucp $2^{+/+}$transplanted mice was found and reported to correlate with enhanced oxidative stress in $\mathrm{Ucp} 2^{--}$transplanted mice. This result strongly suggests furthermore a protective role for UCP2 against atherosclerosis [13].

Respiration Uncoupling and UCPs: Clinical Perspective
Regulatory Functions of UCPs in Type 2 Diabetes

Mellitus

Reduction of the amount of ATP generated through oxidation of fuels by an UCP-stimulated uncoupling procedure suggests UCPs as candidate genes for human obesity or type 2 diabetes mellitus (T2D) [11, 12, 48-50]. Besides a large variety of proposed functions of UCP2, including control of ATP synthesis, regulation of fatty acid metabolism or control of ROS production [4, 8, 22], this UCP is discussed to regulate insulin secretion in pancreatic islets and thereby may play an important role in linking obesity to T2D [11]. Furthermore, mapping of the gene of UCP2 to a region linked to obesity and hyperinsulinaemia as well as the fact that the UCP2 gene was shown to be under control of fatty acids and thyroid hormones in vivo provide strong evidence for a possibly important role in the loss of beta-cell function in diabetes $[26,51]$. High-fat feeding markedly impaired glucose-induced insulin secretion in islets from rats and this was accompanied by an increase in UCP2 levels in the islets. The authors of this observation concluded that hyperlipidaemia induced by high-fat feeding affects insulin secretion in islets by a mechanism which may involve, at least in part, modulation of UCP2 expression [52]. Further experimental evidences support this conclusion by revealing that genetically engineered mice overexpressing different UCP homologues were resistant to diet-induced obesity [12]. In addition, a $-866 \mathrm{G} / \mathrm{A}$ polymorphism in the UCP2 gene, which enhances its transcriptional activity, was associated with increased risk for T2D in obese subjects. Moreover, UCP2 mRNA expression was significantly correlated with insulin resistance $[53,54]$. Accumulating evidence using UCP2 knock-out mice shows that beta-cell UCP2 expression is up-regulated by glucolipotoxic conditions and that increased activity of UCP2 decreases insulin secretion $[11,55]$. The finding that lack of UCP2 dramatically improves insulin secretion constitutes, to date, the most pertinent path to investigations in a therapeutic perspective [55].

\section{UCPs and Body Weight Regulation}

Body weight regulation is a complex phenotype also depending either directly or indirectly on the action of UCPs that mediate dissipation of energy as heat $[48,49]$. When UCP1 was expressed in murine liver using adenoviral vectors in mice with high-fat diet-induced diabetes and obesity and in standard diet-fed lean mice, hepatic UCP1 expression reversed high-fat diet-induced hyperphagia and hypothalamic leptin resistance, as well as insulin resistance in muscle [50]. In transgenic mice ex- 
pressing UCP1 in skeletal muscle resistance towards high-fat diet-induced obesity, lower levels of glucose, insulin and cholesterol as well as an increased metabolic rate have been observed [49]. Thus, enhanced UCP expression in liver and muscle should be considered a new potential therapeutic target for the metabolic syndrome.

Interestingly, when studying 261 subjects from the Quebec Family Study, Oppert et al. [56] found a higher frequency of a specific allele version in the UCP1 gene in individuals who gained more body fat over time. Furthermore, central obesity in whites as reflected by an increased waist-to-hip ratio is discussed to be associated with UCP1 64A/T and UCP3 -55C/T polymorphisms [57]. When assessing the association between the UCP $3-55 \mathrm{C} / \mathrm{T}$ polymorphism and the risk of obesity, the conclusion was drawn that UCP3 $-55 \mathrm{C} / \mathrm{T}$ polymorphism carriers have apparently a lower risk of obesity [58]. In the case of UCP2 a common G/A polymorphism in the UCP2 promoter region is shown to be significantly associated with enhanced adipose tissue mRNA expression by comparison of 340 obese and 256 never-obese middle-aged subjects [48].

Moreover, sex differences have been shown in cold-, diet- and overweight-induced expression of BAT UCP1 and also in correlation of muscle UCP3 with overweight [59]. Male but not female rats showed tendency to have increased overweight-induced levels of abdominal muscle UCP3 mRNA relative to their age-matched controls [60]. Sex-dependent differences, as well as sex differences in body weight gain under a hypercaloric diet, could be related to the different respective biological functions of males and females, taking into account the fact that the gender effect in future studies on obesity could be of interest. Besides UCP1, especially UCP3 expression has been suggested as a potentially important determinant affecting obesity risk, keeping in mind that UCP3 seems to play a prominent role in the regulation of energy metabolism. Most notably, expression of UCP3 mainly in skeletal muscle mitochondria and the potency of skeletal muscle to act as a thermogenic organ make UCP3 an attractive target for studies towards manipulation of energy expenditure to fight disorders such as obesity and T2D. The observation that mice overexpressing human UCP3 in skeletal muscle are hyperphagic but weigh less than their wild-type littermates and show an increased glucose clearance rate provides evidence that skeletal muscle UCP3 has the potential to influence metabolic rate and glucose homeostasis in the whole animal [61]. Furthermore, comparison of the proton leak in diet-resistant and diet-responsive overweight women and the expression and gene characteristics of UCP2 and UCP 3 by Harper et al. [62] leads to the conclusion that proton leak and the expression of UCP3 but not of UCP2 correlates with weight loss success and may be candidates for pharmacological regulation of fat oxidation in obese diet-resistant subjects.

\section{UCPS and Mitochondrial ROS Formation, Cellular Ageing and Apoptosis}

Oxidative stress and mitochondrial dysfunction are associated with disease and ageing. Oxidative stress results from overproduction of ROS generated by mitochondrial respiration, often leading to peroxidation of membrane phospholipids and production of reactive aldehydes [10]. Furthermore, mitochondrial ROS by shortening telomeres are an important determinant in cellular ageing (fig. 2). According to this free radical theory of ageing, oxidative damage from mitochondrial ROS is a major cause of cellular decline, i.e. apoptosis, during ageing. In aged cells, mitochondrial membrane potential $(\mathrm{mt} \Delta \mu \mathrm{H}(+))$ is reduced by a slower respiration and among others this change induces apoptosis [63]. UCPs are described to stimulate respiration by lowering $\mathrm{mt} \Delta \mu \mathrm{H}(+)$ which directly leads to diminished ROS formation and in turn to a reduced frequency of apoptotic events [10, $63,64]$. This protective process mediated by UCPs is also known as 'mild uncoupling' of oxidative phosphorylation [10]. In available literature, particularly UCP2 is described as a potent modulator of mitochondrial generation of ROS, including $\mathrm{H}_{2} \mathrm{O}_{2}, \mathrm{O}^{2-}$ and $\mathrm{OH}$-radical [41]. This supports a role especially for UCP2 in cellular (patho-)physiological processes involving free radicals generated by mitochondria, such as oxidative damage, inflammation or apoptosis $[9,10,14]$. In this context a recently published study is worth to be mentioned. Significant extension in life span of the fly Drosophila melanogaster without compromising fertility or physical activity was shown when human UCP2 (hUCP2) was targeted to the mitochondria of adult fly neurons. In this case, an observed decrease in ROS production and oxidative damage by action of hUCP2 is concluded to be sufficient to extend life span of flies [65]. All actually available data concerning the role of UCPs in apoptosis and ageing have in common that UCPs per se cannot cause apoptosis. There is furthermore a broad consensus in the fact that there are UCP-type specific differences in the role of UCP action leading either to protective or death-sensitizing effects. For example, neurons and their synaptic terminals are found to be protected by the neuron-specific UCP4 as 
well as the neuronal expressed UCP2 against dysfunction and apoptotic death by a mechanism involving suppression of oxyradical production and stabilization of cellular calcium homeostasis $[66,67]$. In contrast to this protective function of UCPs some publications describe UCPs as death-sensitizing components. In an UCP-transfected cell line a higher responsiveness to stimulation of mitochondria-mediated apoptosis as well as a higher mitochondrial $\mathrm{Bax} / \mathrm{Bcl}-2$ ratio, representing a prominent apoptotic marker, were described [68]. The authors of this study deduced that presence of UCPs - in this case UCP3 - sensitizes cells to apoptotic stimuli involving mitochondrial pathways [68].

In a study undertaken to determine whether age-related changes in UCP expression occur, tissue-specific changes of UCP2 and UCP 3 gene expression were found to be associated with ageing [69]. An observed increased UCP2 expression in ageing liver was proposed to limit ATP production and was related to changes in mitochondrial gene expression in older animals [69]. Furthermore, an in vivo observed decrease in skeletal muscle aerobic capacity with advanced age in humans was interpreted as a consequence of the dramatic reduction of UCP3 content associated with decreased uncoupled respiration of skeletal muscle mitochondria [70]. Consistent with a tighter coupling, increased free radical production might contribute to the metabolic compromise in ageing. Taken together, the data suggest a potential role of UCPs as tissue-specific regulators of mitochondrial ROS formation and ATP production during apoptotic processes and cellular ageing.

\section{UCPs in Neoplastic Events}

Cancer cell survival depends on adaptive mechanisms including modulation of oxidative stress responses and acquiring drug resistance $[15,71]$. Tumour cell drug resistance is the major problem in achieving successful cancer treatment. Moreover, drug-resistant cells express high levels of mitochondrial UCP2 [71]. UCP2 expression is increased for example in most human colon cancers and the level of expression appears to correlate with the degree of neoplastic changes [71]. These findings may foster the idea that UCP2 as a negative regulator of ROS production is part of a novel adaptive response by which oxidative stress is modulated in cancer cells. Furthermore, not only in colon cancer expression particularly of UCP2 was found to be elevated. In some hepatocarcinoma cell lines and in activated mouse myeloid leukemia cells UCP2 protein is expressed 10-fold higher compared with undifferentiated non-transformed cells [72, 73]. In addition, up-regulation of UCP2 mRNA has been demonstrated in thyroid oxyphilic oncocytoma tumours in comparison to the paired control tissues. This rare subgroup of thyroid tumours is characterized by a significantly lower ATP synthesis, suggesting that a coupling defect in oxidative phosphorylation may be a cause of mitochondrial hyperplasia $[74,75]$. A similar and further confirming observation was made by analyzing the human tumour HeLa cell line, where increased UCP 2 expression leads to rapid and dramatic fall in mitochondrial membrane potential and to reduction of mitochondrial NADH and intracellular ATP [16]. Another approach in research for a possible role of UCPs in cancer development was performed with the implantation of a fast-growing lung tumour into mice which resulted in a clear cachectic state characterized by a profound muscle wasting and was accompanied by a significant increase in both UCP2 and UCP 3 gene expression in skeletal muscle and heart [76]. Interestingly, comparison of mRNA levels of UCP3 in skeletal muscle from gastrointestinal adenocarcinoma patients with the respective controls led to the conclusion that elevations in muscle UCP3 activity may enhance energy expenditure and this in turn could contribute to tissue catabolism during tumour burden [77]. Confirming results of another study, where a mouse model system shows significant elevations of UCP mRNA levels in different tissues in response to injection of an adenocarcinoma-secreted lipidmobilizing factor, additionally suggest that UCPs may serve to increase fat catabolism in cancer cachexia [78]. These and other results [79] agree with the possible roles of UCPs in participation in a counter-regulatory cytoprotective mechanism to lower production of ROS and in parallel in the increase of energy expenditure associated with tumour growth. On the other hand, the latter mentioned putative contribution of UCPs to the well-characterized abnormalities of metabolism observed in cancer as for example weight loss attributable to enhanced energy expenditure could not be confirmed in the case of pancreatic cancer [80].

\section{Clinical Perspectives and Therapeutic Potential of the UCP Family Members}

There is much to be done to decipher the full array of actions of UCPs since mechanistic explanations for reported effects are still not available (table 3). For this reason, it is difficult to comment upon the therapeutic potential of UCPs and the benefits of their pharmacological targeting. One of the current challenges and obstacles of 
UCP research is the lack of broad understanding not only of their exact function in cellular physiology but also of which endogenous substances activate UCPs and, perhaps more importantly, which pharmacological compounds could selectively activate different UCPs. The availability of this information will be quintessential to an in-depth analysis of the functionality of these proteins as pharmacologic target structures. However, from the early signs it becomes clear that elucidation of physiological functions of UCPs may lead to identification of novel drug targets for prevention and treatment of different diseases.

Thus, UCP1 and brown fat thermogenesis is and remains a target of continued interest for attenuating nutrient efficiency and counteracting obesity and insulin resistance since future strategies could involve the conversion of white fat cells into thermogenic brown-fat-like adipocytes [81]. However, most physiological studies have not enhanced the understanding of the roles of UCP2, UCP3 and other members of this family. Phenotypes of mice with inactivated UCP2 or UCP3 genes are not related to either defective body temperature or body weight regulation and it has been proposed that these transporters are involved in fatty acid metabolism and in down-regulation of mitochondrial ROS production linking them with epidemic diseases like cancer or chronic inflammation.

In summary, these are still 'early days' in UCP research and a meaningful understanding of the functionality of this mitochondrial transporter family is till now not present at all. Nevertheless, the promising recent findings summarized in this review provoke considerable opti-
Table 3. What the clinician should know about UCPs and respiration uncoupling

Respiration uncoupling and energy expenditure are inherent parts of mitochondrial physiology.

UCPs are mitochondrial transporters present in the mitochondrial inner membrane.

UCP1 acts as a proton carrier and uncouples respiratory chain action from ATP synthase by using oxidation energy for thermogenesis.

Physiological and biochemical roles of UCP1 homologuous UCP2, UCP3, UCP4, BMCP1 and KMCP1 are uncertain.

UCP-mediated respiration uncoupling seems to be implicated in important pathological processes (diabetes, obesity, atherosclerosis, cancer).

UCPs $=$ Uncoupling proteins.

mism that pharmacologic targeting of UCPs in future will offer an entirely unique approach to fight against today's most challenging diseases.

\section{Acknowledgements}

The work of our laboratory is supported by Centre National de la Recherche Scientifique, the Institut National de la Santé et de la Recherche Médicale, the Association de Recherche sur le Cancer and the Institut de Recherche Servier. T.N. is supported by the grand ECFP6 'Diabesity' contract No. LSHM-CT-20003-503041 in aid of the European Union.

\section{References}

1 Brustovetsky NN, Amerkanov ZG, Yegorova ME, Mokhova EN, Skulachev VP: Carboxyatractylate-sensitive uncoupling in liver mitochondria from ground squirrels during hibernation and arousal. FEBS Lett 1990;272: 190-192.

-2 Brustovetsky NN, Dedukhova VI, Egorova MV, Mokhova EN, Skulachev VP: Inhibitors of the ATP/ADP antiporter suppress stimulation of mitochondrial respiration and $\mathrm{H}+$ permeability by palmitate and anionic detergents. FEBS Lett 1990;272:187-189.

$\checkmark 3$ Brand MD, Pakay JL, Ocloo A, Kokoszka J, Wallace DC, Brookes PS, Cornwall EJ: The basal proton conductance of mitochondria depends on adenine nucleotide translocase content. Biochem J 2005;392:353-362.
Krauss S, Zhang CY, Lowell BB: The mitochondrial uncoupling-protein homologues. Nat Rev Mol Cell Biol 2005;6:248-261.

$\checkmark 5$ Mozo J, Emre Y, Bouillaud F, Ricquier D, Criscuolo F: Thermoregulation: what role for UCPs in mammals and birds? Biosci Rep 2005;25:227-249.

6 Jezek P, Garlid KD: Mammalian mitochondrial uncoupling proteins. Int J Biochem Cell Biol 1998;30:1163-1168.

7 Schrauwen P, Hesselink MK: The role of uncoupling protein 3 in fatty acid metabolism: protection against lipotoxicity? Proc Nutr Soc 2004;63:287-292.

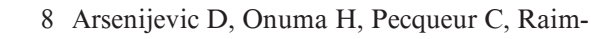
bault S, Manning BS, Miroux B, Couplan E, Alves-Guerra MC, Goubern M, Surwit R, Bouillaud F, Richard D, Collins S, Ricquier D: Disruption of the uncoupling protein-2 gene in mice reveals a role in immunity and reactive oxygen species production. Nat Genet 2000; 26:435-439.

$\checkmark 9$ Brand MD, Affourtit C, Esteves TC, Green K, Lambert AJ, Miwa S, Pakay JL, Parker N: Mitochondrial superoxide: production, biological effects, and activation of uncoupling proteins. Free Radic Biol Med 2004;37:755-767.

10 Echtay KS, Esteves TC, Pakay JL, Jekabsons MB, Lambert AJ, Portero-Otin M, Pamplona R, Vidal-Puig AJ, Wang S, Roebuck SJ, Brand $\mathrm{MD}$ : A signalling role for 4-hydroxy-2-nonenal in regulation of mitochondrial uncoupling. EMBO J 2003;22:4103-4110. 
11 Chan CB, Saleh MC, Koshkin V, Wheeler MB: Uncoupling protein 2 and islet function. Diabetes 2004;53(suppl 1):S136-S142.

- 12 Son C, Hosoda K, Ishihara K, Bevilacqua L, Masuzaki H, Fushiki T, Harper ME, Nakao K: Reduction of diet-induced obesity in transgenic mice overexpressing uncoupling protein 3 in skeletal muscle. Diabetologia 2004;47:47-54.

13 Blanc J, Alves-Guerra MC, Esposito B, Rousset S, Gourdy P, Ricquier D, Tedgui A, Miroux $\mathrm{B}$, Mallat Z: Protective role of uncoupling protein 2 in atherosclerosis. Circulation 2003;107: 388-390.

14 Brand MD, Buckingham JA, Esteves TC, Green K, Lambert AJ, Miwa S, Murphy MP, Pakay JL, Talbot DA, Echtay KS: Mitochondrial superoxide and aging: uncoupling-protein activity and superoxide production. Biochem Soc Symp 2004;71:203-213.

15 Harper ME, Antoniou A, Villalobos-Menuey E, Russo A, Trauger R, Vendemelio M, George A, Bartholomew R, Carlo D, Shaikh A, Kupperman J, Newell EW, Bespalov IA, Wallace SS, Liu Y, Rogers JR, Gibbs GL, Leahy JL, Camley RE, Melamede R, Newell MK: Characterization of a novel metabolic strategy used by drug-resistant tumor cells. FASEB J 2002; 16:1550-1557.

-16 Mills EM, Xu D, Fergusson MM, Combs CA, $\mathrm{Xu}$ Y, Finkel T: Regulation of cellular oncosis by uncoupling protein 2. J Biol Chem 2002; 277:27385-27392.

17 Brown GC: Control of respiration and ATP synthesis in mammalian mitochondria and cells. Biochem J 1992;284:1-13.

18 Kalckar HM: 50 years of biological research from oxidative phosphorylation to energy requiring transport regulation. Annu Rev Biochem 1991;60:1-37.

-19 Palmieri F: The mitochondrial transporter family (SLC25): physiological and pathological implications. Pflügers Arch 2004;447:689709 .

20 Skulachev VP: Uncoupling: new approaches to an old problem of bioenergetics. Biochim Biophys Acta 1998;1363:100-124.

-21 Porter RK: Mitochondrial proton leak: a role for uncoupling proteins 2 and 3? Biochim Biophys Acta 2001;1504:120-127.

-22 Ricquier D, Bouillaud F: The uncoupling protein homologues: UCP1, UCP2, UCP3, StUCP and AtUCP. Biochem J 2000;345:161-179.

-23 Klingenberg M, Winkler E, Echtay K: Uncoupling protein, $\mathrm{H}+$ transport and regulation. Biochem Soc Trans 2001;29:806-811.

-24 Sanchis D, Fleury C, Chomiki N, Goubern M, Huang Q, Neverova M, Gregoire F, Easlick J, Raimbault S, Levi-Meyrueis C, Miroux B, Collins S, Seldin M, Richard D, Warden C, Bouillaud F, Ricquier D: BMCP1, a novel mitochondrial carrier with high expression in the central nervous system of humans and rodents, and respiration uncoupling activity in recombinant yeast. J Biol Chem 1998;273:3461134615 .
25 Haguenauer A, Raimbault S, Masscheleyn S, Gonzalez-Barroso Mdel M, Criscuolo F, Plamondon J, Miroux B, Ricquier D, Richard D, Bouillaud F, Pecqueur C: A new renal mitochondrial carrier, $\mathrm{KMCP} 1$, is up-regulated during tubular cell regeneration and induction of antioxidant enzymes. J Biol Chem 2005; 280:22036-22043.

26 Fleury C, Neverova M, Collins S, Raimbault $\mathrm{S}$, Champigny O, Levi-Meyrueis C, Bouillaud F, Seldin MF, Surwit RS, Ricquier D, Warden $\mathrm{CH}$ : Uncoupling protein-2: a novel gene linked to obesity and hyperinsulinemia. Nat Genet 1997; 15:269-272.

27 Boss O, Samec S, Paoloni-Giacobino A, Rossier C, Dulloo A, Seydoux J, Muzzin P, Giacobino JP: Uncoupling protein-3: a new member of the mitochondrial carrier family with tissuespecific expression. FEBS Lett 1997;408:3942.

28 Mao W, Yu XX, Zhong A, Li W, Brush J, Sherwood SW, Adams SH, Pan G: UCP4, a novel brain-specific mitochondrial protein that reduces membrane potential in mammalian cells. FEBS Lett 1999;443:326-330.

29 Runswick MJ, Powell SJ, Nyren P, Walker JE: Sequence of the bovine mitochondrial phosphate carrier protein: structural relationship to ADP/ATP translocase and the brown fat mitochondria uncoupling protein. EMBO J 1987;6: 1367-1373.

30 Jezek P, Garlid KD: Mammalian mitochondrial uncoupling proteins. Int J Biochem Cell Biol 1998;30:1163-1168.

- 31 Jezek P, Engstova H, Zackova M, Vercesi AE, Costa AD, Arruda P, Garlid KD: Fatty acid cycling mechanism and mitochondrial uncoupling proteins. Biochim Biophys Acta 1998; 1365:319-327.

32 Klingenspor M: Cold-induced recruitment of brown adipose tissue thermogenesis. Exp Physiol 2003;88:141-148.

-33 Enerback S, Jacobsson A, Simpson EM, Guerra C, Yamashita $\mathrm{H}$, Harper ME, Kozak LP: Mice lacking mitochondrial uncoupling protein are cold-sensitive but not obese. Nature 1997;387:90-94.

34 Harper ME, Gerrits MF: Mitochondrial uncoupling proteins as potential targets for pharmacological agents. Curr Opin Pharmacol 2004;4:603-607.

35 Rousset S, Alves-Guerra MC, Mozo J, Miroux B, Cassard-Doulcier AM, Bouillaud F, Ricquier D: The biology of mitochondrial uncoupling proteins. Diabetes 2004;53(suppl 1): S130-S135.

36 Bezaire V, Spriet LL, Campbell S, Sabet N, Gerrits M, Bonen A, Harper ME: Constitutive UCP3 overexpression at physiological levels increases mouse skeletal muscle capacity for fatty acid transport and oxidation. FASEB J 2005; 19:977-979.

37 Hong Y, Fink BD, Dillon JS, Sivitz WI: Effects of adenoviral overexpression of uncoupling protein-2 and -3 on mitochondrial respiration in insulinoma cells. Endocrinology 2001;142: 249-256.
38 Horvath TL, Warden CH, Hajos M, Lombardi A, Goglia F, Diano S: Brain uncoupling protein 2: uncoupled neuronal mitochondria predict thermal synapses in homeostatic centers. J Neurosci 1999; 19:10417-10427.

- 39 Andrews ZB, Diano S, Horvath TL: Mitochondrial uncoupling proteins in the CNS: in support of function and survival. Nat Rev Neurosci 2005;6:829-840.

40 Nohl H, Kozlov AV, Gille L, Staniek K: Cell respiration and formation of reactive oxygen species: facts and artefacts. Biochem Soc Trans 2003;31:1308-1311.

41 Negre-Salvayre A, Hirtz C, Carrera G, Cazenave R, Troly M, Salvayre R, Penicaud L, Casteilla L: A role for uncoupling protein-2 as a regulator of mitochondrial hydrogen peroxide generation. FASEB J 1997;11:809-815.

42 Bai Y, Onuma H, Bai X, Medvedev AV, Misukonis M, Weinberg JB, Cao W, Robidoux J, Floering LM, Daniel KW, Collins S: Persistent nuclear factor-kappa B activation in Ucp2 ${ }^{-/-}$ mice leads to enhanced nitric oxide and inflammatory cytokine production. J Biol Chem 2005;280:19062-19069.

- 43 Alves-Guerra MC, Rousset S, Pecqueur C, Mallat Z, Blanc J, Tedgui A, Bouillaud F, Cassard-Doulcier AM, Ricquier D, Miroux B: Bone marrow transplantation reveals the in vivo expression of the mitochondrial uncoupling protein 2 in immune and nonimmune cells during inflammation. J Biol Chem 2003; 278:42307-42312.

44 Rousset S, Alves-Guerra MC, Ouadghiri-Bencherif S, Kozak LP, Miroux B, Richard D, Bouillaud F, Ricquier D, Cassard-Doulcier AM: Uncoupling protein 2, but not uncoupling protein 1 , is expressed in the female mouse reproductive tract. J Biol Chem 2003;278: 45843-45847.

45 Du XL, Edelstein D, Dimmeler S, Ju Q, Sui C, Brownlee M: Hyperglycemia inhibits endothelial nitric oxide synthase activity by posttranslational modification at the Akt site. J Clin Invest 2001;108:1341-1348.

46 Park JY, Park KG, Kim HJ, Kang HG, Ahn JD, Kim HS, Kim YM, Son SM, Kim IJ, Kim YK, Kim CD, Lee KU, Lee IK: The effects of the overexpression of recombinant uncoupling protein 2 on proliferation, migration and plasminogen activator inhibitor 1 expression in human vascular smooth muscle cells. Diabetologia 2005;48:1022-1028.

47 Bernal-Mizrachi C, Weng S, Li B, Nolte LA, Feng C, Coleman T, Holloszy JO, Semenkovich CF: Respiratory uncoupling lowers blood pressure through a leptin-dependent mechanism in genetically obese mice. Arterioscler Thromb Vasc Biol 2002;22:961-968.

48 Esterbauer H, Schneitler C, Oberkofler H, Ebenbichler C, Paulweber B, Sandhofer F, Ladurner G, Hell E, Strosberg AD, Patsch JR, Krempler F, Patsch W: A common polymorphism in the promoter of UCP2 is associated with decreased risk of obesity in middle-aged humans. Nat Genet 2001;28:178-183. 
>49 Li B, Nolte LA, Ju JS, Han DH, Coleman T, Holloszy JO, Semenkovich CF: Skeletal muscle respiratory uncoupling prevents diet-induced obesity and insulin resistance in mice. Nat Med 2000;6:1115-1120.

-50 Ishigaki Y, Katagiri H, Yamada T, Ogihara T, Imai J, Uno K, Hasegawa Y, Gao J, Ishihara H, Shimosegawa T, Sakoda H, Asano T, Oka $\mathrm{Y}$ : Dissipating excess energy stored in the liver is a potential treatment strategy for diabetes associated with obesity. Diabetes 2005;54: 322-332.

-51 Brown JE, Thomas S, Digby JE, Dunmore SJ: Glucose induces and leptin decreases expression of uncoupling protein-2 mRNA in human islets. FEBS Lett 2002;513:189-192.

\52 Briaud I, Kelpe CL, Johnson LM, Tran PO, Poitout V: Differential effects of hyperlipidemia on insulin secretion in islets of Langerhans from hyperglycemic versus normoglycemic rats. Diabetes 2002;51:662-668.

-53 D’Adamo M, Perego L, Cardellini M, Marini MA, Frontoni S, Andreozzi F, Sciacqua A, Lauro D, Sbraccia P, Federici M, Paganelli M, Pontiroli AE, Lauro R, Perticone F, Folli F, Sesti G: The -866A/A genotype in the promoter of the human uncoupling protein 2 gene is associated with insulin resistance and increased risk of type 2 diabetes. Diabetes 2004; 53:1905-1910.

54 Bulotta A, Ludovico O, Coco A, Di Paola R, Quattrone A, Carella M, Pellegrini F, Prudente S, Trischitta V: The common -866G/A polymorphism in the promoter region of the UCP2 gene is associated with reduced risk of type 2 diabetes in Caucasians from Italy. J Clin Endocrinol Metab 2005;90:1176-1180.

-55 Wallace DC: Animal models for mitochondrial disease. Methods Mol Biol 2002;197:3-54.

-56 Oppert JM, Vohl MC, Chagnon M, Dionne FT, Cassard-Doulcier AM, Ricquier D, Perusse $\mathrm{L}$, Bouchard $\mathrm{C}$ : DNA polymorphism in the uncoupling protein (UCP) gene and human body fat. Int J Obes Relat Metab Disord 1994; 18:526-531.

57 Herrmann SM, Wang JG, Staessen JA, Kertmen E, Schmidt-Petersen K, Zidek W, Paul M, Brand E: Uncoupling protein 1 and 3 polymorphisms are associated with waist-to-hip ratio. J Mol Med 2003;81:327-332.

-58 Alonso A, Marti A, Corbalan MS, MartinezGonzalez MA, Forga L, Martinez JA: Association of UCP3 gene -55C $>$ T polymorphism and obesity in a Spanish population. Ann Nutr Metab 2005;49:183-188.

59 Rodriguez AM, Palou A: Uncoupling proteins: gender dependence and their relation to body weight control. Int J Obes Relat Metab Disord 2004;28:500-502.
60 Rodriguez AM, Roca P, Bonet ML, Pico C, Oliver P, Palou A: Positive correlation of skeletal muscle UCP3 mRNA levels with overweight in male, but not in female, rats. Am J Physiol Regul Integr Comp Physiol 2003;285: R880-R888.

61 Clapham JC, Arch JR, Chapman H, Haynes A, Lister C, Moore GB, Piercy V, Carter SA, Lehner I, Smith SA, Beeley LJ, Godden RJ, Herrity N, Skehel M, Changani KK, Hockings PD, Reid DG, Squires SM, Hatcher J, Trail B, Latcham J, Rastan S, Harper AJ, Cadenas S, Buckingham JA, Brand MD, Abuin A: Mice overexpressing human uncoupling protein-3 in skeletal muscle are hyperphagic and lean. Nature 2000;406:415-418.

62 Harper ME, Dent R, Monemdjou S, Bezaire V, Van Wyck L, Wells G, Kavaslar GN, Gauthier A, Tesson F, McPherson R: Decreased mitochondrial proton leak and reduced expression of uncoupling protein 3 in skeletal muscle of obese diet-resistant women. Diabetes 2002;51: 2459-2466.

63 Kagawa Y, Cha SH, Hasegawa K, Hamamoto T, Endo H: Regulation of energy metabolism in human cells in aging and diabetes: $\mathrm{FoF}(1)$, mtDNA, UCP, and ROS. Biochem Biophys Res Commun 1999;266:662-676.

64 Sullivan PG, Springer JE, Hall ED, Scheff SW: Mitochondrial uncoupling as a therapeutic target following neuronal injury. J Bioenerg Biomembr 2004;36:353-356.

65 Fridell YW, Sanchez-Blanco A, Silvia BA, Helfand SL: Targeted expression of the human uncoupling protein 2 (hUCP2) to adult neurons extends life span in the fly. Cell Metab 2005; 1 : 145-152.

66 Mattson MP, Liu D: Mitochondrial potassium channels and uncoupling proteins in synaptic plasticity and neuronal cell death. Biochem Biophys Res Commun 2003;304:539-549.

67 Mattiasson G, Shamloo M, Gido G, Mathi K, Tomasevic G, Yi S, Warden CH, Castillio RF, Melcher T, Gonzalez-Zulueta M, Nikolich K, Wieloch T: Uncoupling protein-2 prevents neuronal death and diminishes brain dysfunction after stroke and brain trauma. Nat Med 2003;9:1062-1068.

68 Dejean L, Camara Y, Sibille B, Solanes G, Villarroya F: Uncoupling protein-3 sensitizes cells to mitochondrial-dependent stimulus of apoptosis. J Cell Physiol 2004;201:294-304.

69 Barazzoni R, Nair KS: Changes in uncoupling protein-2 and -3 expression in aging rat skeletal muscle, liver, and heart. Am J Physiol Endocrinol Metab 2001;280:E413-E419.

70 Kerner J, Turkaly PJ, Minkler PE, Hoppel CL: Aging skeletal muscle mitochondria in the rat: decreased uncoupling protein-3 content. Am J Physiol Endocrinol Metab 2001;281:E1054E1062.

-71 Horimoto M, Resnick MB, Konkin TA, Routhier J, Wands JR, Baffy G: Expression of uncoupling protein-2 in human colon cancer. Clin Cancer Res 2004;10:6203-6207.
72 Nishio K, Qiao S, Yamashita H: Characterization of the differential expression of uncoupling protein 2 and ROS production in differentiated mouse macrophage-cells $(\mathrm{Mm} 1)$ and the progenitor cells (M1). J Mol Histol 2005; 36:35-44.

73 Carretero MV, Torres L, Latasa U, GarciaTrevijano ER, Prieto J, Mato JM, Avila MA: Transformed but not normal hepatocytes express UCP2. FEBS Lett 1998;439:55-58.

74 Jacques C, Baris O, Prunier-Mirebeau D, Savagner F, Rodien P, Rohmer V, Franc B, Guyetant S, Malthiery Y, Reynier P: Two-step differential expression analysis reveals a new set of genes involved in thyroid oncocytic tumors. J Clin Endocrinol Metab 2005;90:23142320.

75 Savagner F, Franc B, Guyetant S, Rodien P, Reynier P, Malthiery Y: Defective mitochondrial ATP synthesis in oxyphilic thyroid tumors. J Clin Endocrinol Metab 2001;86:49204925.

76 Busquets S, Almendro V, Barreiro E, Figueras M, Argiles JM, Lopez-Soriano FJ: Activation of UCPs gene expression in skeletal muscle can be independent on both circulating fatty acids and food intake. Involvement of ROS in a model of mouse cancer cachexia. FEBS Lett 2005; 579:717-722.

77 Collins P, Bing C, McCulloch P, Williams G: Muscle UCP-3 mRNA levels are elevated in weight loss associated with gastrointestinal adenocarcinoma in humans. Br J Cancer 2002; 86:372-375.

78 Bing C, Russell ST, Beckett EE, Collins P, Taylor S, Barraclough R, Tisdale MJ, Williams G: Expression of uncoupling proteins-1, -2 and -3 mRNA is induced by an adenocarcinoma-derived lipid-mobilizing factor. $\mathrm{Br} \mathrm{J}$ Cancer 2002;86:612-618.

79 Sanchis D, Busquets S, Alvarez B, Ricquier D, Lopez-Soriano FJ, Argiles JM: Skeletal muscle UCP2 and UCP3 gene expression in a rat cancer cachexia model. FEBS Lett 1998;436:415418.

80 DeJong CH, Busquets S, Moses AG, Schrauwen P, Ross JA, Argiles JM, Fearon KC: Systemic inflammation correlates with increased expression of skeletal muscle ubiquitin but not uncoupling proteins in cancer cachexia. Oncol Rep 2005;14:257-263.

81 Hansen JB, Jorgensen C, Petersen RK, Hallenborg P, De Matteis R, Boye HA, Petrovic N, Enerback S, Nedergaard J, Cinti S: Retinoblastoma protein functions as a molecular switch determining white versus brown adipocyte differentiation. Proc Natl Acad Sci USA 2004;101:4112-4117. 